\title{
Reduction in cytokine release from human monocytes by modifications in cell wall structure of Staphylococcus aureus induced by subinhibitory concentrations of oxacillin
}

\author{
F.-J. SCHMITZ*†, J. VERHOEF†, U. HADDING*, H.-P. HEINZ* and M. E. JONES† \\ *Institute for Medical Microbiology and Virology, Heinrich-Heine University Düsseldorf, Germany and \\ $\dagger$ Eijkman-Winkler Institute for Medical Microbiology, Utrecht University, The Netherlands
}

\begin{abstract}
Whole bacterial cells of Staphylococcus aureus as well as purified staphylococcal peptidoglycan (PG) have been demonstrated to stimulate human monocytes to release cytokines. Hypothesising that the phenomenon of changes induced by $\beta$-lactam antibiotics in cell-wall composition may alter the immunological properties of the intact cell wall as well as of purified cell-wall components, this study assessed whether cytokine release by human monocytes is altered if cells from strains grown in the presence or absence of sub-minimal inhibitory concentrations of oxacillin are used as stimuli. Whole bacterial cells and isolated PG from these strains, grown in the presence of oxacillin, showed a significantly reduced stimulation of tumour necrosis factor- $\alpha$, interleukin (IL)$1 \beta$ and IL-6 release by human monocytes in a concentration-dependent fashion. The serum-induced potentiation of cytokine production by human monocytes in response to PG with modified cross-linking was also reduced. These observations may have particular relevance for staphylococcal infections, in which clinically achievable $\beta$ lactam concentrations do not suppress staphylococcal growth yet may alter and possibly enhance virulence.
\end{abstract}

\section{Introduction}

In the pathogenesis of staphylococcal infections, various cell-wall components of the bacteria, e.g., peptidoglycan (PG), teichoic acid (TA) and lipoteichoic acid (LTA), have been shown to be capable of inducing septic shock-like symptoms, analogous to lipopolysaccharides (LPS) in gram-negative infections [1-7]. PG and TA, the major staphylococcal cell-wall components, have been shown to stimulate human monocytes to release tumour necrosis factor $\alpha(\mathrm{TNF} \alpha)$, interleukin (IL)- $1 \beta$ and IL-6 in a concentration-dependent manner $[1,2]$. Also, whole bacterial cells of Staphylococcus aureus stimulated TNF production. Human serum greatly potentiates PG-induced TNF release by human monocytes and in the presence of serum PG was almost as potent as endotoxin [5].

Results of previous studies $[1,2,8]$ suggested that a certain size or tertiary configuration of the $\mathrm{PG}$

Received 6 Aug. 1997; accepted 31 Oct. 1997.

Corresponding author: Dr F-J. Schmitz. macromolecule, or both, is required to induce cytokine release by human monocytes. PG has a rigid structure and consists of repeating units of $\mathrm{N}$-acetylglucosamine $(\beta 1-4)$ linked to N-acetylmuramic acid. Through the carboxyl residue of each $\mathrm{N}$-acetylmuramic acid residue, and oligopeptide (stem peptide) is attached, usually a tetrapeptide with minor amounts of pentapeptide. Typically, the PG is cross-linked by a chain of five glycine residues from the $\varepsilon$-amino group of Llysine in one peptide to the D-alanine residue in position 4 of an adjacent peptide. The formation of a peptide bond between glycine and D-alanine is the final, cross-linking reaction in $S$. aureus PG biosynthesis, and the transpeptidase catalysing this reaction is a critical target of $\beta$-lactam antibiotics [9].

None of these single products (muramyl dipeptide, tetra- and pentaglycine, PG stem peptide) were able to induce TNF release from human monocytes [2]. Purified PG is an insoluble material and sonication of PG for three 10-s periods resulted in a maximal capacity for induction of TNF release [2]. However, prolonged sonication led to a decrease in this capacity, probably because of either disruption of the tertiary 
structure or reduction in size of the macromolecule, or both. Furthermore, treatment of PG with different enzymes resulted in a decrease in the capacity to induce TNF release. Although the enzymes used act at different sites of the PG macromolecule, they all reduce its size and disrupt its tertiary structure [2].

$\beta$-lactam antibiotics exert their antibacterial effects by blocking the assembly of newly synthesised PG into the bacterial cell wall. Exposure of staphylococci to $\beta$-lactam antibiotics results in the release of soluble PG (sPG) molecules and in a reduction of PG crosslinking [10-14]. The high degree of cross-linking in the staphylococcal cell wall was established in earlier studies [10-15]. In the cell wall of normally growing cells, $>60 \%$ of the muropeptides were made up of trimeric and higher oligomeric species. In the PG of cells grown in the presence of concentrations of methicillin below the minimal inhibitory concentration (MIC), the proportion of oligomers fell to $c$. $15 \%$ and they were replaced by the monomeric and dimeric disaccharide pentapeptides carrying the pentaglycyl substituent resulting in a modified tertiary cell-wall structure [10-15]. MRSA contain the mecA gene which, in addition to normal penicillin-binding proteins (PBP), encodes an additional PBP, PBP2A, which has a low affinity for $\beta$-lactam antibiotics and is believed to represent a $\beta$-lactam-intensive transpeptidase. It is conceivable that PBP2A becomes functional only when the bacteria are exposed to antibiotics in the medium. To test this hypothesis, de Jonge and Tomasz [14] analysed PG of a highly resistant MRSA strain grown in the presence of a range of sub-MICs of methicillin. In the presence of methicillin, MRSA produce a lower proportion of muropeptide trimers and higher oligomers, which are replaced by monomers and dimers carrying the pentaglycine bridge. This might have an effect on the stimulation of cytokine release by staphylococcal PG.

Hypothesising that the phenomenon of $\beta$-lactaminduced changes in cell-wall composition may alter the immunological properties of the intact cell wall as well as of purified cell-wall components (PG and TA), the present study assessed whether cytokine release by human monocytes is altered if whole bacterial cells, as well as PGs with or without modified cross-linking induced by growth of staphylococci in the presence or absence of sub-MIC oxacillin, are used as stimuli. Furthermore, the serum-induced potentiation of TNF production was investigated with $\mathrm{PG}$ with or without modified cross-linking.

These investigations have particular relevance for infections caused by methicillin-resistant staphylococ$\mathrm{ci}$, in which clinically achievable $\beta$-lactam concentrations do not suppress staphylococcal growth yet may modulate immunological properties of the staphylococcal cell wall.

\section{Materials and methods}

\section{Bacterial strains}

Three clinical isolates of methicillin-susceptible $S$. aureus (MSSA) (strains 112, 221 and 307) and three clinical isolates of methicillin-resistant $S$. aureus (MRSA) (strains 119, 267 and 343) derived from blood cultures from patients with bacteraemia were included in the study and used for preparation of PG and TA. The presence of toxic shock syndrome toxin 1 and staphylococcal enterotoxins $\mathrm{A}-\mathrm{E}$ was determined in culture medium by commercially standardised test kits (TST-RPLA-test, SET-RPLA-test, Oxoid, Unipath, Basingstoke, Hants) and by probing for the presence of the respective genes by polymerase chain reaction. None of the strains was found to be positive for any of the genes.

\section{Antibiotics}

A stock solution of oxacillin (Sigma) in $10 \mathrm{~mm}$ phosphate-buffered saline (PBS, $\mathrm{pH}$ 7.4) was prepared and stored at $-70^{\circ} \mathrm{C}$ until use. MIC values for all $S$. aureus strains were determined by standard dilution techniques and were as follows: MSSA strain 112, $1 \mathrm{mg} / \mathrm{L}$; MSSA strain 221, $0.5 \mathrm{mg} / \mathrm{L}$; MSSA strain $307,1 \mathrm{mg} / \mathrm{L}$ and MRSA strain $119,128 \mathrm{mg} / \mathrm{L}$; MRSA strain 267, $256 \mathrm{mg} / \mathrm{L}$; MRSA strain 343, $256 \mathrm{mg} / \mathrm{L}$.

\section{Generation of heat-killed S. aureus or formalin- killed Escherichia coli strains}

To stimulate human monocytes with whole bacteria, colonies were inoculated into Mueller-Hinton Broth (Difco) in the presence or absence of $0.5 \mathrm{MIC}$ of oxacillin and incubated for $24 \mathrm{~h}$ at $37^{\circ} \mathrm{C}$. As a control, E. coli $\mathrm{O} 111: \mathrm{B} 4$ was also included in the study. Before the TNF induction assay, bacteria were washed three times with PBS ( $\mathrm{pH} 7.4$ ), counted (by spectrophotometric methods), heat inactivated for $30 \mathrm{~min}$ at $60^{\circ} \mathrm{C}$, and resuspended in PBS to a final concentration of $5 \times 10^{10} \mathrm{cfu} / \mathrm{ml}$. E. coli O111:B4 was grown in Mueller-Hinton broth at $37^{\circ} \mathrm{C}$ for $24 \mathrm{~h}$, washed three times with PBS and counted. The bacteria were killed by incubation in formaldehyde $0.1 \%$ in saline at $37^{\circ} \mathrm{C}$ for $1 \mathrm{~h}$ and washed three times in medium 199 enriched with Earle's salt solution without serum and antibiotics. Sterility was confirmed by incubation of the killed bacteria on blood agar overnight. Counts estimated spectrophotometrically were correlated to cfu by constructing standard curves relating optical density to colony counts by direct plating for each bacterial strain.

\section{Preparation of staphylococcal $P G$ and TA}

PG and TA were prepared from all $S$. aureus strains according to the method of Peterson et al. [16, 17]. 
Bacteria were grown in peptone yeast extract (PYK) medium (containing yeast extract $0.5 \% \mathrm{w} / \mathrm{v}, 1.3 \mathrm{mM}$ $\mathrm{K}_{2} \mathrm{HPO}_{4}$, and $1.1 \mathrm{mM}$ glucose, $\mathrm{pH} 7.2-7.4$, and incubated at $37^{\circ} \mathrm{C}$ for $2-4 \mathrm{~h}$. Log-phase bacteria were inoculated into $10 \mathrm{~L}$ of PYK medium (in the presence or absence of $0.5 \mathrm{MIC}$ of oxacillin) and incubated at $37^{\circ} \mathrm{C}$ for $24 \mathrm{~h}$ with shaking. Bacteria were harvested by centrifugation $\left(5000 \mathrm{~g}, 4^{\circ} \mathrm{C}, 10 \mathrm{~min}\right)$ and washed three times with cold distilled water. Bacterial cells were disrupted with a bead beater (Biospec Products, Bartlesville, OK, USA) containing sterile glass beads ( $0.1 \mathrm{~mm}$ diameter). The bead beater was operated for five cycles of $90 \mathrm{~s}$ each, with 90 -s intervals between cycles. After sedimentation of the beads, the supernate was collected and the beads were washed three times. The pooled supernates from these washing procedures were centrifuged $\left(1000 \mathrm{~g}, 4^{\circ} \mathrm{C}, 10 \mathrm{~min}\right)$ to remove any remaining glass beads. The supernates were centrifuged $\left(14000 \mathrm{~g}, 4^{\circ} \mathrm{C}, 4 \mathrm{~min}\right)$, and the white top layer of the pellet, containing bacterial cell walls, was removed. Cell walls were resuspended in cold distilled water and washed. Gram's stain was then used to confirm the absence of intact staphylococcal cells. The cell walls were resuspended in sodium dodecyl sulphate (BDH Chemicals, Poole, $2 \% \mathrm{w} / \mathrm{v}$ ) and incubated overnight. The material was washed twice with distilled water and thereafter with $0.05 \mathrm{M} \mathrm{NaH} \mathrm{NO}_{4}$ ( $\mathrm{pH} 7.0$ ) and $0.05 \mathrm{M}$ Tris- $\mathrm{HCl}(\mathrm{pH} 7.5)$. Cell walls were resuspended in $200 \mathrm{ml}$ of $0.05 \mathrm{M}$ Tris- $\mathrm{HCl}$ containing $5 \mathrm{mM} \mathrm{MgCl}$, DNAase (Boehringer $\mathrm{GmbH}$, Mannheim, Germany) $5 \mathrm{mg} / \mathrm{L}$ and RNAase (Boehringer) $5 \mathrm{mg} / \mathrm{L}$ and stirred slowly at $37^{\circ} \mathrm{C}$ for $1 \mathrm{~h}$. Subsequently, trypsin (Sigma) $200 \mathrm{mg} / \mathrm{L}$ was added and the mixture was stirred for a further $4 \mathrm{~h}$. After centrifugation, the pellet was resuspended in $50 \mathrm{ml}$ of distilled water, mixed with $50 \mathrm{ml}$ of phenol (Merck, Darmstadt, Germany) $80 \%$, and stirred at room temperature for $30 \mathrm{~min}$. After subsequent centrifugation, the cell-wall fraction was collected carefully from the interface, resuspended in distilled water and washed five times with cold distilled water. The fraction was resuspended in $20 \mathrm{ml}$ of trichloroacetic acid $10 \% \mathrm{w} / \mathrm{v}$ to remove TA and stirred at $4^{\circ} \mathrm{C}$ for $24 \mathrm{~h}$. A crude PG preparation was then obtained by centrifugation and the supernate was retained. This trichloroacetic acid extraction procedure was repeated once and the TA-containing supernates were used for further purification of TA. To obtain purified PG, the crude $\mathrm{PG}$ preparation was resuspended in trichloroacetic acid $10 \% \mathrm{w} / \mathrm{v}$ and heated at $60^{\circ} \mathrm{C}$ for $90 \mathrm{~min}$ to ensure complete removal of TA. PG was then washed four-to-six times with cold distilled water, lyophilised and weighed. The TA-containing supernate pool was mixed with 5 volumes of cold ethanol $95 \%$ and allowed to precipitate overnight. After centrifugation $\left(5000 \mathrm{~g}, 4^{\circ} \mathrm{C}, 15 \mathrm{~min}\right), \mathrm{TA}$ was redissolved in a minimal volume of trichloroacetic acid and reprecipitated with 5 volumes of cold ethanol. TA was washed three times with acetone by centrifugation $(12000 \mathrm{~g}$, $4^{\circ} \mathrm{C}, 10 \mathrm{~min}$ ) and then lyophilised.

\section{Chemical characterisation of $P G$}

PG was hydrolysed in sealed tubes with $6 \mathrm{M} \mathrm{HCl}$ at $110^{\circ} \mathrm{C}$ for $18 \mathrm{~h}$. Acid was removed under vacuum in the presence of $\mathrm{KOH}$. The amino-acid composition was determined with an amino-acid analyser (Alpha Plus; Pharmacia LKB, Uppsala, Sweden). The purity of the PGs, as determined by amino-acid analysis, showed the amino acids serine, glutamine, glycine, alanine and lysine, to be present in the following ratios: PG MSSA strain 112, 1:1:5:3:1; PG MSSA strain 221, 1:1:2:1:1; PG MSSA strain 307, 1:1:4:3:1; PG MRSA strain 119, 1:1:3:2:1; PG MRSA strain 267, 1:1:4:2:1 and PG MSSA strain 343, 1:1:5:2:1. Non-PG amino acids, notably leucine and isoleucine, were not detected. Contamination of PG with free fatty acids or phospholipids was below the detection limit of the gas chromatographic assays used $(0.01 \mathrm{mM})$. PG was practically free of TA, as shown by the low phosphorus content of the PG preparations $(1.0-7.3 \mathrm{mg} / \mathrm{g})$. Phosphorus was determined as described by Bartlett [18].

\section{Endotoxin contamination}

All experiments were performed aseptically to avoid endotoxin contamination. PG and TA were tested for endotoxin contamination with the Limulus amoebocyte lysate assay (LAL, Chromogenix, Molndal, Sweden). In all of the preparations, tested in a concentration of $10 \mathrm{mg} / \mathrm{L}$, the endotoxin content was $\leqslant 2 \mathrm{mg} / \mathrm{L}$ (limit of sensitivity of the assay). Polymyxin B sulphate (Sigma) was added to all PG and TA preparations to a final concentration of $5 \mathrm{mg} / \mathrm{L}$ and the mixtures were incubated for $30 \mathrm{~min}$ before use.

\section{$P G$ and $T A$}

PG and TA were suspended in $20 \mathrm{~mm}$ PBS $(1 \mathrm{~g} / \mathrm{L})$, sonicated on ice at $30000 \mathrm{~Hz}$ (Sonifier B12; Branson, Danbury, CT, USA) three times for $10 \mathrm{~s}$ each, and stored at $-20^{\circ} \mathrm{C}$. Before use, the stock suspension was sonicated again as described above.

\section{Enzyme treatment of $P G$}

In some experiments, PG preparations were treated with the enzymes lysostaphin (L7386; Sigma), lysozyme (Fluka, Buchs, Switzerland) and mutanolysin (M9901; Sigma). Incubation with the enzymes was in PBS (final concentration, $10 \mathrm{mg} / \mathrm{L}$ ) for $4 \mathrm{~h}$ at $37^{\circ} \mathrm{C}$. Subsequently, the enzymes were inactivated by heat treatment $\left(10 \mathrm{~min}\right.$ at $\left.100^{\circ} \mathrm{C}\right)$.

\section{$L P S$}

LPS from E. coli O111:B4 (Sigma) was dissolved in pyrogen-free water $(2 \mathrm{~g} / \mathrm{L})$ and sonicated on ice as described for $\mathrm{PG}$. The $\mathrm{pH}$ was adjusted to 7.4 with triethylamine $3 \%$, and the solution was stored at $-20^{\circ} \mathrm{C}$. Before use, the solution was sonicated in a water bath for $5 \mathrm{~min}$. 


\section{Serum sources}

Blood was drawn from 35 healthy human volunteers after informed consent was given. Sera were pooled and stored in small volumes at $-70^{\circ} \mathrm{C}$ until use; the pool is referred to as a human pooled serum (HPS). The immunoglobulin G (IgG) content was estimated by radial immunodiffusion with LC-Partigen plates (Behringwerke Marburg AG, Marburg, Germany). HPS contained $13 \mathrm{~g}$ of $\mathrm{IgG} / \mathrm{L}$. C1-depleted serum was obtained by treating and centrifuging HPS with polyethylene glycol $3.5 \%$ as described by Neoh et al. [19], while C3/C4-depleted serum was prepared by treating HPS with methylamine as described by Jessen et al. [20]. In some experiments, serum was heated at $56^{\circ} \mathrm{C}$ for $30 \mathrm{~min}$ to inactivate complement components.

\section{Monocyte isolation and stimulation}

Human peripheral blood mononuclear cells were isolated from buffy coats of healthy donors. Centrifugation on a Ficoll-Paque density gradient (Pharmacia LKB) was performed as described by Boyum [21]. Monocytes $(10 \mathrm{~g} / \mathrm{L})$ were suspended in medium 199 , enriched with Earle's salt solution without serum or antibiotics. The cells were transferred to 96-well flat-bottomed tissue culture plates (Nunc, Kamstrup, Denmark) and incubated in air with $\mathrm{CO}_{2} 5 \%$ at $37^{\circ} \mathrm{C}$ for $1 \mathrm{~h}$ to allow adherence. Non-adherent cells were removed by aspiration, and the monolayer of monocytes (examined by trypan blue and May-Grünwald/Giemsa staining, $>98 \%$ viable and $>94 \%$ monocytes) was then stimulated with $100 \mu \mathrm{l}$ of whole bacteria, PG, TA or LPS at the concentrations indicated. These stimuli were tested with and without pre-incubation with serum (HPS, C1-depleted HPS and C3/C4-depleted HPS) $5 \%$ at room temperature for 10 min. After incubation of the monocytes in air with $\mathrm{CO}_{2} 5 \%$ at $37^{\circ} \mathrm{C}$ for $18 \mathrm{~h}$, the supernates were collected and centrifuged $(10000 \mathrm{~g}, 5 \mathrm{~min})$ to remove cells. Control monocytes were incubated with medium 199 without additions. Supernates were stored at $-70^{\circ} \mathrm{C}$ before performing the assay of cytokines.

\section{Cytokine assays}

Quantitation of TNF $\alpha$, IL- $1 \beta$ and IL- 6 in monocyte supernates was performed with ELISA kits (Medgenix Diagnostics, Brussels, Belgium). Sample concentrations were read from a dose-response curve obtained with reference cytokines. The sensitivity was $3 \mathrm{mg} / \mathrm{L}$ for all tests. Because of the higher levels of cytokines in the pre-incubation experiments with serum, supernates were routinely diluted four times before testing; this resulted in a sensitivity of $12 \mathrm{mg} / \mathrm{L}$ for the diluted samples. Experiments were done in triplicate and repeated four times on separate days with different donor cells. Results were expressed in $\mathrm{mg} / \mathrm{L}$.

\section{Statistical evaluation}

Data are expressed as the means (SEM) of independent experiments. Student's $t$ test was used to estimate the statistical significance of the results. Differences with $\mathrm{p}$ values of $<0.05$ were considered significant.

\section{Results}

TNF release by human monocytes induced by purified $P G$ from strains grown in the presence of various oxacillin concentrations

Table 1 shows that purified staphylococcal PG $(100 \mathrm{mg} / \mathrm{L})$ from MRSA and MSSA grown in medium 199 without oxacillin induced release of TNF by human monocytes. When MSSA and MRSA were grown in the presence of $\geqslant 1 / 16 \mathrm{MIC}$ of oxacillin, significantly less $(\mathrm{p}<0.05$; Table 1$)$ TNF release by human monocytes was induced by purified PG from these strains. Furthermore, no difference in TNF release was observed between MSSA and MRSA strains nor between PGs from strains grown in the presence of each oxacillin concentration tested.

\section{Induction of TNF release by human monocytes stimulated with heat-killed $S$. aureus strains incubated with or without 0.5 MIC of oxacillin}

Table 2 shows that whole bacterial cells of MSSA and MRSA as well as the control E. coli O111:B4 strain stimulated TNF production by human monocytes. No difference was observed between MSSA and MRSA with reference to the stimulatory capacity. All TNF values obtained after stimulation with MSSA and MRSA strains grown in the presence of $0.5 \mathrm{MIC}$ of oxacillin were significantly lower. This reduction in TNF release with whole bacterial cells was more pronounced than the effect observed with purified PG.

Table 1. Release of TNF by human monocytes $\left(10^{6} / \mathrm{ml}\right)$ induced by staphylococcal PG $(100 \mathrm{mg} / \mathrm{L})$ from MSSA ${ }^{*}$ or MRSA $\dagger$ as determined by EIA and effect of incubation with different oxacillin concentrations

\begin{tabular}{lcc}
\hline $\begin{array}{l}\text { Oxacillin } \\
\text { concentration in } \\
\text { growth medium }\end{array}$ & $\begin{array}{c}\text { Mean (SEM) TNF } \\
\text { concentration (ng/L) }\end{array}$ & $\begin{array}{c}\text { TNF (compared to } \\
\text { control) }\end{array}$ \\
\hline MSSA & & - \\
0 (medium 199) & $2650(220)$ & 21 \\
1/16 MIC & $2090(240)$ & 20 \\
1/8 MIC & $2120(150)$ & 24 \\
1/4 MIC & $2010(170)$ & 24 \\
1/2 MIC & $2020(190)$ & - \\
MRSA & & 22 \\
0 (medium 199) & $2740(340)$ & 24 \\
1/16 MIC & $2140(210)$ & 22 \\
1/8 MIC & $2090(280)$ & 21 \\
1/4 MIC & $2130(250)$ & \\
1/2 MIC & $2160(230)$ & \\
\hline
\end{tabular}

*PGs from MSSA strains 112, 221 and 307 and $†$ PGs from MRSA strains 119,267 and 343 were used, and data were pooled. PG preparations included polymyxin B $10 \mathrm{mg} / \mathrm{L}$ (final concentration). 
Table 2. TNF concentrations by EIA in the supernate of human monocytes $\left(10^{6} / \mathrm{ml}\right)$ stimulated with heat-killed oxacillin-susceptible $S$. aureus (MSSA) and oxacillinresistant $S$. aureus strains (MRSA) and formalin-killed E. coli at a concentration of $10^{8} \mathrm{cfu} / \mathrm{ml}$

\begin{tabular}{|c|c|c|c|}
\hline \multirow[b]{2}{*}{ Strain no. } & \multicolumn{2}{|c|}{$\begin{array}{c}\text { Mean (SEM) TNF concentration } \\
\text { (ng/L) after stimulation with } \\
\text { S. aureus grown }\end{array}$} & \multirow{2}{*}{$\begin{array}{c}\text { Percentage } \\
\text { decrease in TNF } \\
\text { release }^{\dagger}\end{array}$} \\
\hline & without oxacillin & with oxacillin & \\
\hline MSSA 112 & $2340^{*}(410)$ & $1460(230)$ & 38 \\
\hline MSSA 221 & $2720 \quad(560)$ & $1640(390)$ & 40 \\
\hline MSSA 307 & $2540 \quad(480)$ & $1710(350)$ & 33 \\
\hline MRSA 119 & $2450 \quad(390)$ & $1510(250)$ & 39 \\
\hline MRSA 267 & $2670 \quad(650)$ & $1680(320)$ & 37 \\
\hline MRSA 343 & $2810 \quad(540)$ & $1620(330)$ & 42 \\
\hline E. coli & $2200 \quad(410)$ & ND & \\
\hline
\end{tabular}

ND, not determined

* Means (SEM) of four separate experiments with monocytes of four different donors are shown.

${ }^{\dagger}$ All TNF values with MSSA and MRSA strains incubated in the presence of oxacillin were significantly reduced $(p<0.05)$ compared to TNF values obtained with untreated strains.

\section{Release of TNF, IL-1 $\beta$ and IL-6 by human} monocytes induced by various concentrations of $P G$ from MRSA strain 119 and by purified $P G$ from MSSA and MRSA strains grown in the presence or absence of 0.5 MIC of oxacillin

The release of TNF, IL- $1 \beta$ and IL- 6 induced by purified PG from MRSA strain 119 was found to be concentration dependent (Table 3). A PG concentration of $\geqslant 1 \mathrm{mg} / \mathrm{L}$ was required to achieve detectable cytokine release from human monocytes in the EIA. Cytokine values obtained with $\mathrm{PG}$ concentrations of $10 \mathrm{mg} / \mathrm{L}$ and $100 \mathrm{mg} / \mathrm{L}$ from MRSA strain 119 grown in the presence of $0.5 \mathrm{MIC}$ of oxacillin were significantly reduced in comparison to TNF values obtained with PG from the same strain grown in the absence of oxacillin.

PG $(100 \mathrm{mg} / \mathrm{L})$ from other strains of MRSA and MSSA grown in medium without oxacillin similarly induced the release of TNF, IL- $1 \beta$ and Il- 6 by human monocytes, whereas growth in the presence of $0.5 \mathrm{MIC}$ of oxacillin caused significantly less cytokine release by human monocytes than was induced by purified PG (Table 4). In general, levels of cytokines induced by PG $(100 \mathrm{mg} / \mathrm{L})$ did not inhibit monocyte TNF release induced by PG $(100 \mathrm{mg} / \mathrm{L})$ from MSSA and MRSA, grown in the presence or absence of 0.5 MIC of oxacillin, whereas the induction of TNF release in response to LPS $(100 \mathrm{mg} / \mathrm{L})$ from $E$. coli O111:B4 was completely abolished by polymyxin B (Table 4).

Release of TNF by human monocytes induced by various concentrations of staphylococcal $P G$ from MRSA strain 119 in the presence of HPS

TNF release by monocytes induced by PG was greatly enhanced in the presence of HPS 5\% (Table 5). At all PG concentrations, HPS $5 \%$ significantly $(p<0.05)$ enhanced TNF release $c$. 10 -fold. The potentiation effect of HPS was reduced with PG from MRSA strain 119 grown in the presence of $0.5 \mathrm{MIC}$ of oxacillin. Heat inactivation of HPS decreased its enhancing effect on TNF release; significant effects $(p<0.05)$ were seen only at PG concentrations of 10 and $100 \mathrm{mg} / \mathrm{L}$. No difference in relative reduction of the serum

Table 3. Release of TNF, IL- $1 \beta$ and IL- 6 by human monocytes induced by staphylococcal PG from MRSA strain 119

\begin{tabular}{lccc}
\hline & \multicolumn{2}{c}{ Cytokine release (ng/L) after growth of } \\
strain 119 & $\begin{array}{c}\text { Percentage change in } \\
\text { Monocyte stimulus }\end{array}$ \\
\cline { 2 - 3 } cytokine concentration
\end{tabular}

*Means (SEM) of four separate experiments with monocytes of four different donors are shown. PG preparations included $10 \mu \mathrm{g}$ of polymyxin $\mathrm{B} / \mathrm{ml}$ (final concentration).

$\dagger \mathrm{TNF}, \mathrm{Il}-1 \beta$ and IL-6 values obtained with $10 \mathrm{mg} / \mathrm{L}$ and $100 \mathrm{mg} / \mathrm{L}$ PG concentrations were significantly different $(p<0.05)$ when PGs were obtained from untreated and treated isolates. 
Table 4. Release of TNF, IL- $1 \beta$ and IL- 6 by human monocytes $\left(10^{6} / \mathrm{ml}\right)$ induced by staphylococcal PG from MSSA and MRSA

\begin{tabular}{|c|c|c|c|c|}
\hline \multirow[b]{3}{*}{ Monocyte stimulus } & \multicolumn{4}{|c|}{ Cytokine release (ng/L) after growth of strains } \\
\hline & \multicolumn{2}{|c|}{ without oxacillin } & \multicolumn{2}{|c|}{ with oxacillin } \\
\hline & - Polymyxin B & + Polymyxin B & - Polymyxin B & + Polymyxin B \\
\hline \multicolumn{5}{|l|}{$\overline{\mathrm{TNF}}$} \\
\hline $\begin{array}{l}\text { LPS }(100 \mu \mathrm{g} / \mathrm{L}) \\
\text { E. coli } 0111: \mathrm{B} 4\end{array}$ & $2300(440)$ & 0 & ND & ND \\
\hline $\begin{array}{l}\text { PG }(100 \mathrm{mg} / \mathrm{L}) \\
\mathrm{MSSA}^{\ddagger}\end{array}$ & $2650(220)$ & $2580(230)$ & $2020(190)^{\dagger}$ & $1960(210)$ \\
\hline $\begin{array}{l}\text { PG }(100 \mathrm{mg} / \mathrm{L}) \\
\text { MRSA }^{\S}\end{array}$ & $2740(340)$ & $2630(310)$ & $2160(230)^{\dagger}$ & $2020(320)$ \\
\hline \multicolumn{5}{|l|}{ IL $-1 \beta$} \\
\hline $\begin{array}{l}\text { LPS }(100 \mu \mathrm{g} / \mathrm{L}) \\
\text { E. coli O111:B4 }\end{array}$ & $6540(530)$ & ND & ND & \\
\hline $\begin{array}{l}\text { PG }(100 \mathrm{mg} / \mathrm{L}) \\
\text { MSSA }^{\ddagger}\end{array}$ & $6980(490)$ & ND & $5310(430)^{\dagger}$ & ND \\
\hline $\begin{array}{l}\text { PG }(100 \mathrm{mg} / \mathrm{L}) \\
\text { MRSA }^{\S}\end{array}$ & $7340(580)$ & ND & $5520(390)^{\dagger}$ & ND \\
\hline \multicolumn{5}{|l|}{ IL-6 } \\
\hline $\begin{array}{l}\text { LPS }(100 \mu \mathrm{g} / \mathrm{L}) \\
\text { E. coli } \mathrm{O} 111: \mathrm{B} 4\end{array}$ & $2130(230)$ & ND & ND & ND \\
\hline $\begin{array}{l}\text { PG }(100 \mathrm{mg} / \mathrm{L}) \\
\text { MSSA }^{\ddagger}\end{array}$ & $2340(310)$ & ND & $1370(280)^{\dagger}$ & ND \\
\hline $\begin{array}{l}\text { PG }(100 \mathrm{mg} / \mathrm{L}) \\
\text { MRSA }^{\S}\end{array}$ & $2580(290)$ & ND & $1440(310)^{\dagger}$ & ND \\
\hline
\end{tabular}

* Means (SEM) of four separate experiments with monocytes of four different donors are shown.

${ }^{\dagger}$ TNF, IL- $1 \beta$ and IL-6 values obtained after stimulation with PG $100 \mathrm{mg} / \mathrm{L}$ from MSSA and MRSA incubated with and without oxacillin were significantly different $(\mathrm{p}<0.05)$.

${ }^{*}$ PGs from MSSA strains 112, 221 and 307 and ${ }^{\$}$ MRSA strains 119, 267 and 343 were used and data were pooled. PG preparations included polymyxin $\mathrm{B} 10 \mathrm{mg} / \mathrm{L}$ (final concentration)

Table 5. Effect of HPS on release of TNF human monocytes induced by staphylococcal PG from MRSA strain 119

\begin{tabular}{|c|c|c|c|c|c|c|}
\hline \multirow{3}{*}{$\begin{array}{l}\text { Monocyte stimulus PG } \\
(\mathrm{mg} / \mathrm{L})\end{array}$} & \multicolumn{6}{|c|}{ TNF release (ng/L) induced by PG from MRSA strain 119 after incubation } \\
\hline & \multicolumn{2}{|c|}{ without HPS } & \multicolumn{2}{|c|}{ with HPS $5 \%$} & \multicolumn{2}{|c|}{ with heat-inactivated HPS $5 \%$} \\
\hline & - oxa & + oxa & - oxa & + oxa & - oxa & + oxa \\
\hline 0 (medium 199) & $40^{*}(18)$ & $45(21)$ & $38(19)$ & $41(21)$ & $43(21)$ & $43(17)$ \\
\hline 0.1 & $100 \quad(24)$ & $83(19)$ & $1020(180)$ & $796(210)$ & $150(33)$ & $110(19)$ \\
\hline 1 & $280 \quad(61)$ & $210(44)$ & $2960(530)$ & $2250(430)$ & $330(67)$ & $250(57)$ \\
\hline 10 & 1630 & $1180(210)$ & $14740(1210)$ & $11310(1150)$ & $2140(430)$ & $1760(310)$ \\
\hline 100 & $3010 \quad(167)$ & $2100(290)$ & $27330(2130)$ & $21350(2450)$ & $14320(1310)$ & $10180(840)$ \\
\hline
\end{tabular}

oxa, oxacillin $0.5 \mathrm{MIC}$

${ }^{*}$ Means (SEM) of four separate experiments with monocytes of four different donors are shown. PG preparations included $10 \mu \mathrm{g}$ of polymyxin $\mathrm{B} / \mathrm{ml}$ (final concentration).

enhancement by heat inactivation could be observed for PG from MRSA strain 119 grown in the presence or absence of 0.5 MIC of oxacillin.

Staphylococcal PG $(10 \mathrm{mg} / \mathrm{L}$ and $100 \mathrm{mg} / \mathrm{L})$ from MRSA strain 119 grown in the presence or absence of $0.5 \mathrm{MIC}$ of oxacillin was pre-incubated with $5 \% \mathrm{C} 1$ or $\mathrm{C} 3 / \mathrm{C} 4$-depleted serum to investigate the role of these components in the serum-enhanced TNF release and to assess the role of PG structure for complement activation. Depletion resulted in a reduction' of TNF release of $30 \%$ and $50 \%$ for $\mathrm{C} 1$-depleted and $\mathrm{C} 3 / \mathrm{C} 4-$ depleted sera, respectively, compared with the controls (PG $10 \mathrm{mg} / \mathrm{L}$ and $100 \mathrm{mg} / \mathrm{L}$ in the presence of HPS $5 \%$ ). Furthermore, no difference in relative reduction of the effect of serum by $\mathrm{C} 1$ and $\mathrm{C} 3 / \mathrm{C} 4$ depletion was observed for PGs from MRSA strain 119 grown in the presence or absence of $0.5 \mathrm{MIC}$ of oxacillin.

\section{Enzyme treatment of staphylococcal PG}

Digestion of PG by the enzymes lysozyme, lysostaphin and mutanolysin resulted in either a marked reduction or a complete loss of the capacity of PG to induce TNF, IL- $1 \beta$ and IL- 6 release by human monocytes. No difference between PG from MRSA and MSSA or from strains grown in the presence or absence of $0.5 \mathrm{MIC}$ of oxacillin was observed.

\section{Release of TNF, $I L-1 \beta$ and $I L-6$ by human monocytes induced by purified staphylococcal TA}

TA from MSSA and MRSA appeared to be a weaker inducer of cytokines than staphylococcal PG. Reductions of $52 \%, 18 \%$ and $34 \%$ in release of TNF, IL- $1 \beta$ and IL-6, respectively, were measured with human monocytes $\left(10^{9} / \mathrm{L}\right)$ and TA $(100 \mathrm{mg} / \mathrm{L})$ when compared to those values obtained with $\mathrm{PG}(100 \mathrm{mg} / \mathrm{L})$ 
shown in Table 3. Neither the origin of TA (MSSA or MRSA) nor the growth conditions of the strains (presence or absence of $0.5 \mathrm{MIC}$ of oxacillin) significantly affected the release of cytokines by human monocytes.

\section{Discussion}

While considerable attention has been drawn to the possible beneficial effects of subinhibitory levels of antibiotics [22], less appreciated is the finding that selected antibiotics, including those commonly used in the clinical management of serious staphylococcal infection, can alter cell-wall composition and toxin production in a manner that has the potential for deleterious effects on the infected host. For MSSA, the routine administration of $\beta$-lactams to a patient usually achieves supra-inhibitory serum and tissue concentrations so that the described changes in cell-wall composition, with subsequent effects on cytokine release, can be ignored because of the killing of the bacteria. However, MRSA strains do not respond to $\beta$ lactam therapy. If $\beta$-lactams modify cell-wall composition [12-15], release sPG [10-11] and induce toxin production in vivo [23], such therapy would be ineffective and might even be harmful in patients infected with $\beta$-lactam-resistant strains [23]. Therefore our observations are especially important for MRSA although the phenomenon described is also true for MSSA.

The data from the present study show that when MSSA and MRSA were grown in the presence of at least $1 / 16 \mathrm{MIC}$ of oxacillin $(0.03-0.06 \mathrm{mg} / \mathrm{L}$ for tested MSSA and $4-8 \mathrm{mg} / \mathrm{L}$ for tested MRSA) resulting in a modified PG structure, significantly less TNF, IL-1 $\beta$ and IL-6 were released by human monocytes induced by purified PG from these strains. This release of cytokines induced by purified PG was found to be concentration dependent. With reference to the TNF-releasing capacity from human monocytes, no difference between MSSA and MRSA strains could be observed when the stimulant was either whole bacterial cells or purified PG. This suggests that there is no difference in muropeptide composition of MSSA and MRSA in the absence of antibiotic treatment [1214]. With respect to the induction of TNF by whole cells of staphylococci, the results of the present study confirm those reported previously by others $[1,2,4]$ and also show that whole cells provide a much more effective stimulus for TNF induction than the purified PG. In line with this observation, the reduction of TNF release was more pronounced with whole cells from strains grown in the presence of sub-MIC of oxacillin than with purified PG from those strains. This suggests that whole staphylococcal cells contain constituents other than PG, which either acting together or synergistically with $\mathrm{PG}$ are responsible for the higher TNF-inducing capacity of the whole bacterial cells. The findings concerning enzyme treatment of PG are in agreement with previous data [2] showing that the TNF-inducing capacity of staphylococcal PG was lost rapidly when the macromolecule was degraded into smaller fragments by either enzyme treatment or sonification. The lack of TNF-inducing activity of muramyl dipeptide, tetraand penta-glycine, and the PG stem peptide shown by Timmerman and colleagues [2] lends further support to the notion that a certain size or tertiary configuration of the PG macromolecule, or both, is required to induce cytokine release by human monocytes. We assume that the modified muropeptide composition of PG resulting from sub-MIC oxacillin treatment is the main reason for the observed reduction in cytokine release by human monocytes.

As a control, TA was purified from strains incubated with or without oxacillin. TA from MSSA and MRSA appeared to be a weaker inducer of cytokines than staphylococcal PG. This is in line with observations by Mattsson et al. [1]. Neither the origin of TA (MSSA or MRSA) nor the growing conditions of the strains (presence or absence of oxacillin 0.5 MIC) changed significantly the ability to stimulate release of cytokines by human monocytes. Thus, we assume that the structure of TA is unchanged or only modified by sub-MIC of oxacillin, to a minor degree.

The yield of PG and TA produced in the presence of sub-MIC of oxacillin was similar to the yield obtained in normal cells. Furthermore, growth in the presence of methicillin had virtually no effect on the physiology and morphology of the cells. This is in line with observations by de Jonge and Tomasz [12-14] who showed that the only abnormal morphological feature was the presence of diffuse and abnormally wide septa. There were no major changes apparent in the contour sizes of the cells or width of the peripheral cell wall, and the orientations of the septal sides also appeared to be normal. Furthermore, Snowden and Perkins [15] observed neither a difference in growth rate nor in the incorporation of $\mathrm{N}$-acetyl[14C]glucosamine into PG of an MSSA strain treated with $\beta$ lactam antibiotics at 0.5 MIC. Furthermore, the cellwall preparations in the present study appeared to be free of LPS, as indicated by the negative Limulus amoebocyte lysate assay and the lack of effect of polymyxin B on the PG-induced TNF release.

With respect to the serum-induced potentiation of TNF production by human monocytes in response to staphylococcal PG, the results of the present study confirm those reported previously by others $[5,24]$. PG can activate both the classical and alternative pathways of human complement $[17,25,26]$. Human complement factor $\mathrm{C} 5 \mathrm{a}$, one of the split products of complement activation, is known to induce TNF release from monocytes in vitro [27] and to enhance TNF release induced in vivo in the presence of 
endotoxin or whole $S$. epidermidis bacteria [4]. Furthermore, Spika et al. [28] found that PG from $S$. aureus strains contributes to complement activation and the induction of leukopenia and thrombocytopenia. The observation that both $\mathrm{C} 1$ and $\mathrm{C} 3 / \mathrm{C} 4$ depletion, as well as heat inactivation of the serum, diminished the serum-enhanced TNF release induced by $\mathrm{PG}$ indicates that the enhancement is mediated mainly by the activation of the classical complement pathway. The present results confirm previous findings that, in the presence of human serum, staphylococcal PG has a potency similar to LPS inducing TNF release by human monocytes, although $\mathrm{PG}$ alone is much less active than LPS. Thus, complement is an important mediator in enhancing TNF production in staphylococcal infections. The data from the present study indicate that modified muropeptide composition of PG resulting from sub-MIC oxacillin treatment leads to a diminished serum-induced potentiation of TNF production by human monocytes in response to staphylococcal PG. Thus, the degree of activation of the complement system seems to depend on a particular configuration of the PG macromolecule. In line with this observation, no relative difference in the reduction of the serum-potentiating effect by heat inactivation, $\mathrm{C} 1$ and $\mathrm{C} 3 / \mathrm{C} 4$ depletion could be observed for PG from MRSA strain 119 grown in the presence or absence of 0.5 MIC of oxacillin.

In conclusion, these data indicate that the structure of PG is important, not only for the induction of cytokine release by human monocytes, but also for the degree of activation of the complement system. Structural requirements for the induction of cytokines have also been found by Takahashi et al. [29] for endotoxic LPS and for the induction of IL-1 by cell walls. TNF may, on one hand, be deleterious [30], but, on the other hand, essential for an effective host defence against micro-organisms in local and sometimes more systemic infections, as demonstrated by an animal model [31]. In particular circumstances, e.g., when the cytokine network is no longer properly controlled, TNF could be harmful. The in-vitro data with diminished cytokine release induced by complete cells or PG from strains grown in the presence of subMIC of oxacillin, suggest at least that the inappropriate therapeutic use of $\beta$-lactam antibiotics resulting in sub-MIC concentrations may influence the inflammatory response of the host. It can be argued that, for MSSA strains, the routine administration of $\beta$-lactams to a patient usually achieves supra-inhibitory serum and tissue concentrations that may prevent changes in cell-wall composition and the subsequent modified immunological properties. However, in many infections (e.g., abscess, chronic osteomyelitis), antibiotics are not delivered reliably to the infected site in concentrations that are inhibitory or bactericidal even for $\beta$-lactam-susceptible strains because of tissue devitalisation or impaired vascular perfusion. Furthermore, MRSA strains do not respond to $\beta$-lactam therapy. If $\beta$-lactams modify cell-wall composition $[12-15]$, release sPG $[10,11,32]$ and induce toxin production in vivo [23], such subinhibitory therapy might actually be harmful in patients infected with $\beta$ lactam-resistant strains. Therefore, these observations may have particular relevance for staphylococcal infections, in which clinically achievable $\beta$-lactam concentrations do not suppress staphylococcal growth yet may alter and possibly enhance virulence.

We gratefully acknowledge the technical assistance of B. Hofmann and the help of K. P. M. Van Kessel and J. A. G. Van Strijp with preparation of the manuscript.

\section{References}

1. Mattsson E, Verhage L, Rollof J, Fleer A, Verhoef J, van Dijk H. Peptidoglycan and teichoic acid from Staphylococcus epidermidis stimulate human monocytes to release tumor necrosis factor- $\alpha$, interleukin- $1 \beta$ and interleukin-6. FEMS Immunol Med Microbiol 1993; 7: 281-287.

2. Timmerman CP, Mattsson E, Martinez-Martinez $\mathrm{L}$ et al. Induction of tumor necrosis factor from human monocytes by staphylococci and staphylococcal peptidoglycans. Infect Immun 1993; 61: 4167-4172.

3. Vacheron F, Guenounou M, Nauciel C. Adjuvant active peptidoglycans induce the secretion of a cytotoxic factor by macrophages In: Seidl $\mathrm{PH}$, Schleifer $\mathrm{KH}$ (eds) Biological properties of peptidoglycan. New York, W de Gruyter and Co. 1986: 395-400.

4. Wakabayashi G, Gelfand JA, Jung WK, Connolly RJ, Burke JF Dinarello CA. Staphylococcus epidermidis induces complement activation, tumor necrosis factor and interleukin-1, a shock-like state and tissue injury in rabbits without endotoxemia. Comparison to Escherichia coli. J Clin Invest 1991; 87: 1925-1935.

5. Mattsson E, Rollof J, Verhoef J, Van Dijk H, Fleer A. Seruminduced potentiation of tumor necrosis factor alpha production by human monocytes in response to staphylococcal peptidoglycan: involvement of different serum factors. Infect Immun 1994; 62: $3837-3843$

6. Heumann D, Barras C, Severin A, Glauser MP, Tomasz A Gram-positive cell walls stimulate synthesis of tumor necrosis factor alpha and interleukin- 6 by human monocytes. Infect Immun 1994; 62: 2715-2721.

7. De Kimpe SJ, Kengatharan M, Thiemermann C, Vane JR. The cell wall components peptidoglycan and lipoteichoic acid from Staphylococcus aureus act in synergy to cause shock and multiple organ failure. Proc Natl Acad Sci USA 1995; 92: 10359-10363.

8. Martínez-Martínez L, Timmermann CP, Fleer A, Verhoef $\mathbf{J}$ Chemiluminescence of human polymorphonuclear leukocytes after stimulation with whole cells and cell-wall components of Staphylococcus epidermidis. J Med Microbiol 1993; 39: 196-203.

9. Wilkinson BJ. Biology. In: Crossley KB, Archer GL (eds) The staphylococci in human disease. New York, Churchill Livingstone. 1997: 1-38.

10. Zeiger AR, Wong W, Chatterjee AN, Young FE, Tuazon CU. Evidence for the secretion of soluble peptidoglycans by clinical isolates of Staphylococcus aureus. Infect Immun 1982; 37 1112-1118

11. Gold MR, Miller CL, Mishell RI. Soluble non-cross-linked peptidoglycan polymers stimulate monocyte-macrophage inflammatory functions. Infect Immun 1985; 49: 731-741.

12. De Jonge BLM, Chang Y-S, Gage D, Tomasz A. Peptidoglycan composition of a highly methicillin-resistant Staphylococcus aureus strain. J Biol Chem 1992; 267: 11248-11254.

13. De Jonge BLM, Chang Y-S, Gage D, Tomasz A. Peptidoglycan composition in heterogeneous Tn551 mutants of a methicillinresistant Staphylococcus aureus strain. J Biol Chem 1992; 267: 11255-11259.

14. De Jonge BLM, Tomasz A. Abnormal peptidoglycan produced in a methicillin-resistant strain of Staphylococcus aureus grown in the presence of methicillin: functional role for penicillin- 
binding protein 2A in cell wall synthesis. Antimicrob Agents Chemother 1993; 37: 342-346.

15. Snowden MA, Perkins HR. Cross-linking and O-acetylation of peptidoglycan in Staphylococcus aureus (strains H and MR-1) grown in the presence of sub-growth-inhibitory concentration of $\beta$-lactam antibiotics. $J$ Gen Microbiol 1991; 137: 1661-1666.

16. Peterson PK, Wilkinson BJ, Kim Y et al. The key role of peptidoglycan in the opsonization of Staphylococcus aureus. $J$ Clin Invest 1978; 61: 597-609.

17. Wilkinson BJ, Kim Y, Peterson PK, Quie PG, Michael AF. Activation of complement by cell surface components of Staphylococcus aureus. Infect Immun 1978; 20, 388-392.

18. Bartlett GR. Phosphorus assay in column chromatography. $J$ Biol Chem 1959; 234: 466-468.

19. Neoh SH, Gordon TP, Roberts-Thomson PJ. A simple one-step procedure for preparation of $\mathrm{Cl}$-deficient human serum. J Immunol Methods 1984; 69: 277-280.

20. Jessen TE, Barkholt V, Welinder KG. A simple alternative pathway for hemolytic assay of human complement component C3 using methylamine-treated plasma. J Immunol Methods 1983; 60: $89-100$.

21. Boyum A. Isolation of mononuclear cells and granulocytes from human blood. Isolation of mononuclear cells by one centrifugation, and of granulocytes by combining centrifugation and sedimentation at 1 g. Scand J Clin Lab Invest Suppl 1968; 97: $77-89$.

22. Lorian V, Gemmell CG. Effect of low antibiotic concentrations on bacteria: effects on ultrastructure, virulence, and susceptibility to immunodefenses. In: Lorian V (ed) Antibiotics in laboratory medicine, 3 rd edn. Baltimore, Williams and Wilkins 1991: 493-555.

23. Kernodle DS, McGraw PA, Barg NL, Menzies BE, Voladri RKR, Harshman S. Growth of Staphylococcus aureus with nafcillin in vitro induces $\alpha$-toxin production and increases the lethal activity of sterile broth filtrates in a murine model. $J$ Infect Dis 1995; 172: 410-419.

24. Mattsson E, Van Dijk H, Van Kessel K, Verhoef J, Fleer A,
Rollof $\mathbf{J}$. Intracellular pathways involved in tumor necrosis factor-alpha release by human monocytes on stimulation with lipopolysaccharide or staphylococcal peptidoglycan are partly similar. J Infect Dis 1996; 173: 212-218.

25. Verbrugh HA, van Dijk WC, Peters $\mathrm{R}$ et al. Opsonic recognition of staphylococci mediated by cell wall peptidoglycan: antibody-independent activation of human complement and opsonic activity of peptidoglycan antibodies. J Immunol 1980; 124: $1167-1173$.

26. Verbrugh HA, van Dijk WC, Peters $R$, Van Der Tol ME, Verhoef J. The role of Staphylococcus aureus cell-wall peptidoglycan, teichoic acid and protein $\mathrm{A}$ in the processes of complement activation and opsonization. Immunology 1979; 37: 615-621.

27. Barton PA, Warren JS. Complement component C5 modulates the systemic tumor necrosis factor response in murine endotoxic shock. Infect Immun 1993; 61: 1474-1481.

28. Spika JS, Peterson PK, Wilkinson BJ et al. Role of peptidoglycan from Staphylococcus aureus in leukopenia, thrombocytopenia, and complement activation associated with bacteremia. J Infect Dis 1982; 146: 227-234.

29. Takahashi I, Kotani S, Takada H, Shiba T, Kusumoto S. Structural requirements of endotoxic lipopolysaccharides and bacteria cell walls in induction of interleukin-1. Blood Purif 1988; 6: 188-206.

30. Ahmed AJ, Kruse JA, Haupt MT, Chandrasekar PH, Carlson RW. Hemodynamic responses to gram-positive versus gramnegative sepsis in critically ill patients with and without circulatory shock. Crit Care Med 1991; 19: 1520-1525.

31. Nakane A, Mingawa $T$, Kato $K$. Endogenous tumor necrosis factor (cachectin) is essential to host resistance against Listeria monocytogenes infection. Infect Immun 1988; 56: 2563-2569.

32. Mattsson E, Van Dijk H, Verhoef J, Norrby R, Rollof J. Supernatants from Staphylococcus epidermidis grown in the presence of different antibiotics induce differential release of tumor necrosis factor alpha from human monocytes. Infect Immun 1996; 64: 4351-4355. 